\title{
Taxonomy of some important wild/zoo animals found in India
}

\begin{abstract}
The persons engaged in management of wild life are zoo veterinarian, wild life health scientist who should know about taxonomic classification of status of wild fauna to familiarize them with peculiarities of animals which may be of great helpful in management, diagnosis \& treatment of disease. At the global level about 1.6 million living forms have been identified including green plants, fungi, insects, vertebrates, \& m.o. In India about 81251 species of animals accounts for 372 mammals, 1228 birds, 446reptiles, 204 amphibians, 2546 fishes, 5050 molluscs \& 60383 insects. In flora India have $15 \%$ of known world plants. About 372 species of mammals under the class Mammlia reported in India with 3 subclasses. The aim of this study is to come across the baseline classification of wild animals. Through classification we can also know about living and feeding habitats of a particular group of animals. The animals belonging to one group will have some general characters which also help in handling and management of wild animals in zoo or in their natural habitat. ${ }^{1}$

a. Monotremata (eg.spiny anteater)

b. Marsupalia (eg. kangaroo, koala bear)

c. Eutheria: There are 12 different orders have been reported in India. They are Edantata Pholidata. Insectivora, Lagomorpha, Rodentia, Carnivora, Cetacea, Chiroptera, Ungulates (suborders. a Artiodactyla b. Perrisodactyla), Primates, Proboscida, Pinnipedia.
\end{abstract}

Volume 3 Issue 2 - 2018

\author{
Basant Bais \\ Rajasthan University of Veterinary and Animal Sciences, India
}

Correspondence: Basant Bais, Department of Livestock Products Technology, College of Veterinary and Animal Sciences, Rajasthan University of Veterinary and Animal Sciences, Bikaner, Rajasthan, 33400I, India, Email basantbais@gmail.com

Received: February 23, 2018| Published: March 15, 2018

\section{Edantata}

The characteristics features of the animals belonging to this order are
a. Absence of front teeth
b. Long snout
c. Digits have claw e.g. Sloth.

\section{Pholidata}

The characteristics features of the animals belonging to this order are
a. Teeth absent
b. Five clawed digit
c. Live in burrows found in low hills e.g. Pangolins pantadactyla, Indian Pangolin (Manis crassicandata), Chinese pangolin (Manjs).

\section{Insectivora}

The animals belonging to this order are

a. Terrestrial or Nocturnal creature\Posses small pointed teeth

b. Insect eater and

c. Found in forest areas of country e.g. Indian tree shrew, Himalayan tree shrew, Long eared hedgehog, Indian short tailed mole, White tailed mole, Grey musk shrew. ${ }^{2}$

\section{Lagomorpha}

a. The animals belonging to this order posses

b. Canaines c. Herbivorous in nature

d. Long hind legs and

e. Live in burrows e.g. Hares ( Black napped, Himalayan, Desert mouse hare).

\section{Rodentia}

The order Comprises of 32 families and 352 genera. The important characteristics feature of the animals is that there is presence of Incisors e.g. Mouse, Flying squirrel, Giant squirrel, orange bellied, Gebril, Rat, Mouse, Porcupine are found in India. Capybaras are the largest rodent being 1 to $1.3 \mathrm{~m}$ in head and body length \& 36 to $50 \mathrm{~kg}$ in body wt. ${ }^{3}$

\section{Chiroptera}

Only mammals capable of true flight e. g. Bats, the major species of bats found in India are Flying fox, Fruit

bat, pointed bat, Indian false vampire.

\section{Carnivora}
All the animals of the group are
a. Flesh eating mammals
b. Powerful jaws are present
c. Presence of 3 pairs of incisors
d. Canines are large and sharp
e. Limbs with powerful claws

Carnivora include suborder Fissipedia and Pinnipedia. ${ }^{4}$ The Fissipedia has two groups Cat line and Dog line the catline have 
following families

a. Viverridae e.g. Civet, Mongoose

b. Hyaenidae e.g. Hyena

c. Felidae e.g. Lion, Tiger, Panther Lynx, Jungle cat, Desert cat

d. The dog lines have following families

e. Canidae e.g. Wolves, Jackal, Fox, Dogs

f. Ursidae e.g. Bear - Distributed from Himalayas to Kanyakumari. The important bears are Sloth bear, Brown bear, And Himalayan Black Bear.

g. Poryonidae e.g. Racoon \& Panda -Red panda lives in temperate forest of central and eastern Himalayas. They are nocturnal.

h. Mustelidae e.g. Ferret \& Mink

\section{Ungulates}

Comprises of two suborders Perissodactyla and Artiodactyla, Characteristics of Perissodactyla

a. Canines present in males only

b. Odd toed hoofed animals.

The Perissodactyla have following families

a. Rhinocerotide e.g. Rhinoceros

b. Equidae e.g. Equines

The suborder Artiodactyla has following characteristics

a. Even toed hoofed animals.

b. Presence of hollow horns

c. Upper incisors are absent

d. Presence of complex stomach e.g. All even toed hooves mammals like ruminants, swine, hippopotamus etc.

The families of ruminants are

a. Bovidae, e.g. Wild cattle, buffalo, Yak, Bison, Gazzela, etc.

b. Giraffidae e.g. Giraffe and Okapi

c. Cervidae e.g. Deer group like Musk deer, Hog deer, Sambhar, Swamp deer and Hungal

d. Antelopidae e.g. Chinkara, Blackbuck, Chausinga, Nilgai

e. Hippopotamidae e.g. Hippopotamus

f. Suidae e.g.Wild hog

g. Camelidae e.g. Lama, Alpaca.

\section{Proboscida}

The suborder Proboscida has following characteristics

a. Testes abdominal

b. Nose and upper lip forms Probosis c. Two upper incisors modified as tusk e.g. elephant (Elephus maximus).

\section{Primates}

Comprises of 11 families and 60 genera.The major families are

a. Cercopitheicidae -macaques and

b. Colobinae-langur. Major primates found in India are hoolock gibbon, bonnet macaque, rhesus macaque, assames macaque, stump tailed macaque, pig tailed macaque, 1 ion tailed macaque, common langur, golden langur, nilgiri langur, slow loris and slender loris.

\section{Cetacea}

Cetacea are widely distributed and diverse aquatic mammals that consist of the whales, dolphins, and porpoises. Cetaceans are carnivorous and finned. Most species live in the sea, some in rivers.

a. All are aquatic mammals

b. Hairs are absent e.g. dolphin and whale.

\section{Pinnipedia}

Pinnipeds, commonly known as seals, are a widely distributed fin-footed, semiaquatic marine mammals. e.g. seal, sea lion, walrus. ${ }^{5}$

\section{Conclusion}

Thus the important species of Indian wild animals are which are taxonomically mentioned above are widely distributed in different biogeography zones of the country. The wildlife of India is unique, mysterious and fascinating with its diverse ecosystem.

\section{Acknowledgement}

None.

\section{Conflict of interest}

Author declare there is no conflict of interest.

\section{References}

1. Burton M. University dictionary of mammals of the world. $1^{\text {st }}$ ed. Thomas Y Crowell: New York; 1962.

2. Fowler ME. Zoo and wild animal medicines. $2^{\text {st }}$ ed. WB Saunders Company: Philadelphia; 1986.

3. Mace GM, Lande R. Assessing Extinction Threats: Toward a Reevaluation of IUCN Threatened Species Categories. Conserve Biol. 1991;5(2):148157.

4. Prater SH. The book of Indian animals. $1^{\text {st }} \mathrm{ed}$. BNHS: Mumbai; 1971.

5. Jani RG, Patel PR. Glimpses of Indian wildlife wealth: An overview. Intas polivet. 2001;2(2):129-133. 